Center for American Progress

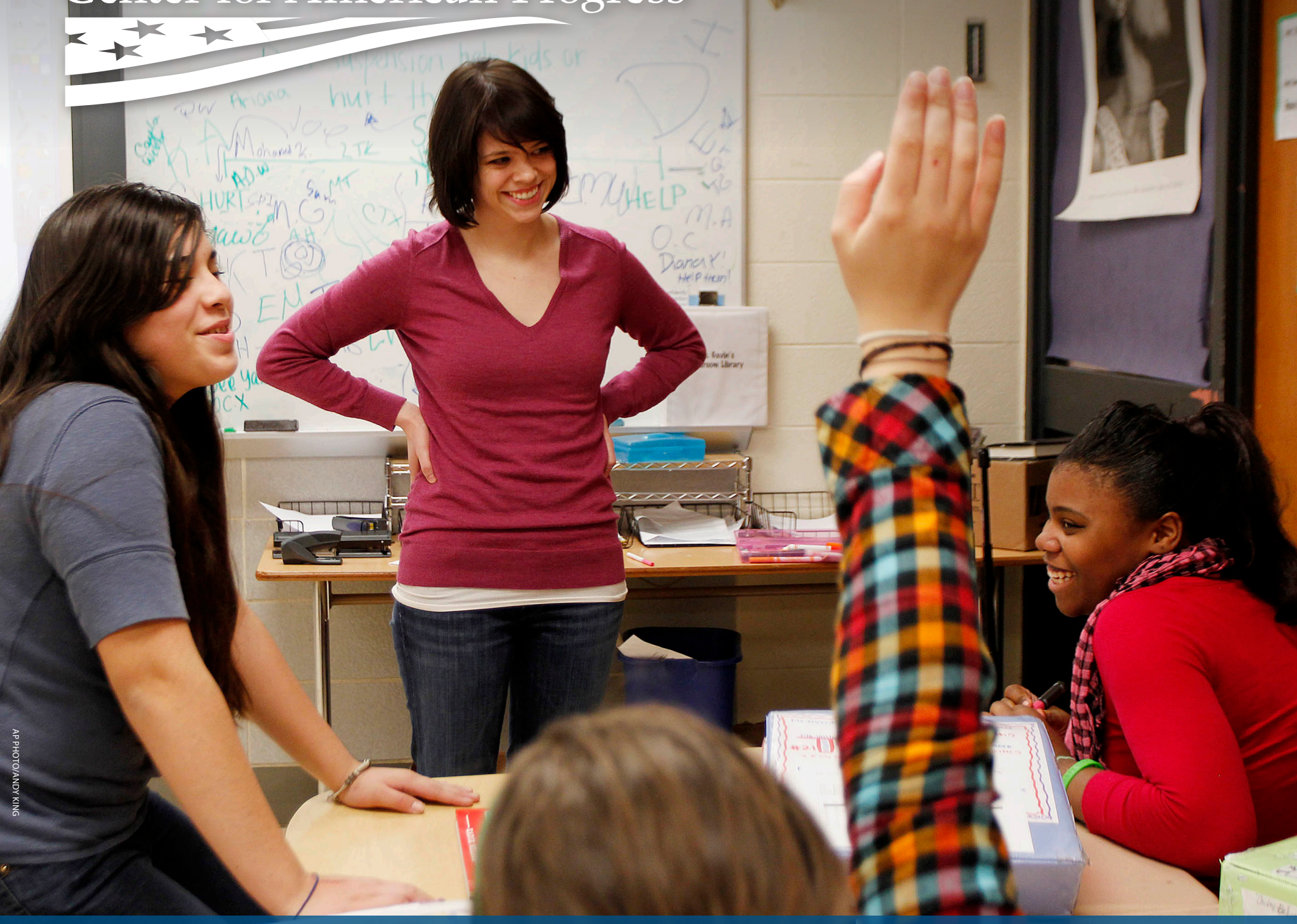

\title{
Getting the Best People into the Toughest Jobs
}

Changes in Talent Management in Education

Allan Odden April 2013 

Center for American Progress

\section{Getting the Best People into the Toughest Jobs}

Changes in Talent Management in Education

Allan Odden April 2013 



\section{Contents}

1 Introduction and summary

5 A look back: Education-talent management at the close of the 20th century

9 Education reform understated the importance of talent

13 Rumblings of change in education-talent management

19 Educator-talent management reform solidifies

23 A new world of talent management in education: Putting strategic talent management at the center of education policy and practice

29 Challenges ahead

33 Reasons underlying monumental changes in talent management

37 Conclusion

39 About the author

41 Endnotes 



\section{Introduction and summary}

It is indisputable that teachers and principals have the greatest impact on student learning. ${ }^{1}$ Unfortunately, the education system has hired and tenured thousands of ineffective teachers and principals, particularly in high-poverty urban and rural schools. As a consequence, these schools have low levels of student learning.

To remedy this problem, the nation is engaged in multiple activities to get effective teachers into all classrooms and effective principals into all schools through more "strategic management" of education talent. Strategic talent management is an approach that manages all human resource programs - recruitment, selection, placement, development, evaluation, tenure, promotion, dismissal, and compensation-around a set of effectiveness metrics that capture instructional practice and student-learning growth. The theory is that effective principals should manage schools in ways that facilitate teachers' acquiring the instructional expertise they need to make them and the school effective- that is to say, successful in dramatically boosting student learning.

The issue of strategic talent management in education leapt onto the policy and practice agenda quite recently. Yet in a short time period, huge changes in policy and practice have occurred. From a set of disjointed policies and even-worse practices, a comprehensive and holistic view of strategic talent management in education is developing, supported by new and ambitious federal and state policies and rapidly changing local practices. Admittedly, policy design still needs significant calibration, and local implementation is far from complete. But the landscape of how teachers and principals — the education talent—are managed is dramatically changing. A once-haphazard mix of approaches is moving toward many more strategic systems that are designed to ensure that only effective teachers and principals are recruited, tenured, retained, and well-compensated - particularly in urban and poor rural communities.

This paper examines the evolving landscape of talent management in education, which is broken out in five sections: 
- Section one: Talent management, or lack thereof, in education at the close of the 20th century

- Section two: Educational change that began at the dawn of the 21 st century

- Section three: Rumblings of change that evolved into comprehensive new federal and state human-capital management policies and local practices

- Section four: Rumblings of change that coalesced into a foundation of change across the country and the new world of talent management

- Section five: Why the focus on talent evolved and quickly assumed such a prominent role in the nation's education policy and practice agendas

In part, due to positive state and local response to federal requirements for new education programs such as Race to the Top, School Improvement Grants, the Teacher Incentive Fund, and No Child Left Behind waivers, states and districts are identifying and using new channels for recruiting better talent into the nation's schools, especially high-poverty schools in urban and rural areas. States and school districts are also developing new ways of evaluating teachers - methods that use a measure of instructional practice and evidence of student learning, and in some cases student surveys on the academic environment. States and districts are then using these new metrics to determine whether or not to tenure teachers, as a condition for promotion, to implement new salary schedules, and for dismissal—instead of seniority.

Though there is steady progress toward designing and implementing all these new policies and practices across the country, there is also opposition, and the road forward will certainly be bumpy. To be successful, these initiatives need to also solve some major challenges such as making the new evaluation systems affordable; ensuring that the scores that teachers receive on their evaluations derive from "cut" scores that are set at rigorous levels in order to accurately identify the most effective and most ineffective teachers; deciding where to put the toughest requirements for entering the teaching professions so the talent that flows from the new recruitment sources are not shut off; and embedding all this in an effective school improvement strategy that is linked to the new Common Core State Standards Initiative.

At the foundation of every one of these reforms is an acknowledgement across policy communities and shared by a growing number of advocates on the ground 
that talent truly matters. In spite of the continuing need to improve curriculum rigor, fund education appropriately, provide quality development and support to teachers, and improve parental support, the undeniable fact remains: There are too few smart and capable people staffing the most challenging schools-people who will work relentlessly to ensure that all students learn. This factor is the impetus for the rapidly changing landscape of human-capital management that is impacting all stages of the educator pipeline.

Among the recommendations we offer is making entry to the profession difficult at every point to ensure that only the top talent meets the entry standards-based on rigorous assessments of content knowledge and by implementing a rigorous "bar exam," which should assess both instructional expertise and impact on student learning — for the full professional license to be required of every novice teacher at some point after three to five years of teaching. This approach supports both traditional and alternative pathways into the profession, while also ensuring that only demonstrably effective teachers earn the full professional license and then tenure-whatever their pathway into the profession. 



\section{A look back: Education-talent management at the close of the 20th century}

Teachers and principals have the greatest impact on student learning. Unfortunately, our public education system, until recently, selected and tenured thousands of ineffective teachers and principals. The result was low levels of student learning, particularly in high-poverty urban school and rural schools. Though the curriculum and instruction in a classroom are critical parts of improving the impact of schooling, the talent teaching this curriculum, as well as the talent managing school systems, are also critical, and more strategic talent management has only recently stepped onto the education policy and practice agenda stage.

As the 20th century closed, hardly anyone talked about talent management in education, let alone strategic talent management. Personnel administration characterized the approach to teacher and principal supervision and management-the focus was just on getting licensed teachers into classrooms and principals into schools with little, if any, attention to their effectiveness. ${ }^{2} \mathrm{Few}$, if any, personnel-administration policies and programs were linked to anything strategic in school systems. The personnel director rarely sat on the superintendent's cabinet. Teacher and principal recruitment were often back-office tasks. And quality reviews mostly involved ensuring that each individual had a license or certificate appropriate to the task.

Although there were studies noting that teacher quality had declined, ${ }^{3}$ especially in urban districts, ${ }^{4}$ there was little analysis of why that quality had declined. In reports published more than a decade ago, there rarely was discussion of poor to nonexistent recruitment policies and practices in urban districts, and scant recognition that urban hiring practices largely were the factors behind city districts often hiring poorly qualified individuals for teaching positions. Further, there was little analysis of the major pipelines of teacher talents that for many urban districts were the lowest-quality institutions of higher education with equally dismal teacher- and administrator-training programs. Report conclusions simply noted the lower quality of teachers in those districts but provided almost no assessment of the causes. 
As recently as 2007 when education reformer Michelle Rhee was named chancellor of Washington, D.C., Public Schools, there was still the assumption across the country that urban districts - not only in the Washington, D.C., school district but also in most large urban districts - were unable to attract top teacher talent. ${ }^{5}$ But what Rhee discovered, and knew even before her appointment, was that the district usually had several applications for every job opening — about 2,500 applicants for the 250 open teaching jobs in 2007 — and that the applicant pool included scores of teachers trained at quality institutions. The Washington, D.C., school district, however, did not begin reviewing applicants for that school year until the end of August when most quality applicants had already been offered jobs by other districts or had simply given up on the district. As a result, the district had to hire from the "leftover" pool of applicants—basically the applicants that no other district wanted. ${ }^{6}$

Recruitment was not the only broken human-resource management practice of schools. A decade ago the view of most teachers and administrators was that nearly all teacher- and principal-evaluation systems were not worth the time or energy spent on them-a view that was supported in the findings and conclusions of several studies of such systems. ${ }^{7}$ Personnel-administration textbooks addressed evaluation issues mostly in terms of process and fairness but rarely in terms of substance such as how to measure teacher instructional practice or principal effectiveness. ${ }^{8}$ At the close of the 20th century, it was rare for a teacher or principal evaluation to seriously address what teachers or principals should know and be able to perform, let alone assess evidence of impact on student learning.

Though state laws specified when tenure - continuing contract, due process, or similar wording, all meaning essentially the same thing as tenure-needed to be conferred, no state law specified the evidence on which tenure should be based, and few, if any, local school districts had rigorous requirements for the substantive basis on which tenure would or would not be awarded. ${ }^{9}$ As a result, however trained and however effective, most teachers received tenure after two to four years on the job. ${ }^{10}$

In short, recruitment was haphazard with little attention to acquiring demonstrably able teachers or administrators; evaluation did not distinguish between effective and ineffective teachers or principals; and tenure was provided to both almost automatically. Of course, without evaluation systems that could parse teachers and principals into categories of effectiveness or quality, there was little evidence on which to deny tenure or to dismiss teachers-one reason why the dismissal process was usually costly and rarely successful. 
Promotion and pay, which are also critical aspects of the human-resource system, were informed almost exclusively by an educator's longevity at a district or in the field. Seniority was the prime factor for both teacher and principal promotion into positions of leadership or practice. A teacher's years of experience was the major factor that determined whether a teacher could move from one school to another, leading to a situation where seniority trumped matching school need with teacher expertise or desire to "buy into" a particular school's instructional approach. And the basis by which both teachers and principals were paid did not align with effectiveness, as neither education degrees nor years of experience-except for more than three to four years of experienceare linked to greater success in boosting student learning. ${ }^{11}$ 



\section{Education reform understated the importance of talent}

Though there was wide acknowledgement of poor teacher quality in many urban school systems, ${ }^{12}$ few education reform initiatives had education talent or its management as their central elements. Instead, the more common view was that education systems with high concentrations of students from poor and ethnicminority backgrounds simply could not attract the best and brightest teachers and administrators, let alone competent education staff to their schools.

While there were efforts to strengthen teacher-training programs, there was little attention given to education-talent management once individuals entered the system. Most education-reform efforts were directed at changing a variety of accountability, fiscal management, and governance structures such as:

- Attracting more money to low-spending school systems

- Adopting more rigorous curriculum standards together with improved assessment of student achievement

- Devolving authority for decision making to schools

- Changing education governance to allow more charter schools, greater choice of public schools, or even provide vouchers to private schools

- Giving mayors control of big-city school systems

- Adopting performance-pay systems

- Enhancing accountability for student achievement such as holding students back if they did not meet certain achievement levels by key transition points in schools

In a few instances school systems began "reconstituting" low-performing schools by changing the people in them but rarely were these initiatives focused on the underlying causes that resulted in ineffective teachers and principals working in these schools. The goal was to simply get a new set of teachers and principals, but reconstitution largely ignored the system that had allowed the school to have such ineffective educator talent in the first place. Moreover, most school reconstitution policies were highly contentious, with the education system usually arguing that it was unfair to kick the adults - the teachers and administrators - out of low- 
performing schools and rejecting the notion that a major root of the problems of these consistently-low performing schools was ineffective educator talent.

Despite all that, there were glimmerings of change. Two new organizations emerged during this period: Teach For America and The New Teacher Project, or TNTP. Both organizations were centrally focused on recruiting top talent into the nation's school systems, particularly in urban and rural districts. These groups recruited and then selected bright individuals with high potential but who lacked traditional teacher preparation to become effective teachers in the education system. Their strategies were quite contentious and generally unsupported by the broader education or policy systems at the time.

Founded by Wendy Kopp in 1990, Teach For America operated on the premise that the key factor for low-student performance in urban school systems was the quality of the teacher talent in the classroom. To address the problem, Teach for America created a strategy to find that quality talent and get them into classrooms in high-poverty urban and rural communities.

In a few short years, Teach For America became highly successful in recruiting graduates from the top colleges in the country, including the universities of Harvard, Princeton, Brown, Duke, Northwestern, and Stanford, to name a few, and placing them in teaching positions in high-need city schools. Over time, Teach For America dramatically increased the number of individuals recruited each year-from an initial group of 500 to 5,800 in 2012 — and today also recruits from the nation's top public research universities. ${ }^{13}$ Teach For America was-and still is-enormously successful in making teaching in high-poverty schools a highly sought opportunity among the "best and brightest" young individuals in the country. Being selected for the Teach For America program has become a mark of distinction among the cadre of smart and capable individuals who attend these high-ranking colleges and universities.

Today Teach For America works in 46 regions in the United States, which comprise hundreds of schools that enroll thousands of students, and produces almost 6,000 teachers a year. ${ }^{14} \mathrm{~A}$ Teach For America recruit's commitment initially was for just two years, though in 2010 the organization reported that 61 percent of its members remained in teaching positions beyond that two-year commitment. ${ }^{15}$ Teach For America has identified the core problem of city schools as a lack of high-quality talent—high-academic ability as measured by SAT or other college-entrance exam scores - and has figured out how to get that talent into 
high-poverty classrooms, a phenomenon the public-education system itself had not thought possible and something not addressed systemically by the highereducation establishment.

A spin-off organization begun by Teach For America alums, initially led by Michelle Rhee, focused on additional avenues for getting top talent into the same high-poverty classrooms. In 1997 TNTP began recruiting "early career changers," individuals who had entered highly paid and high-powered positions in law, management consulting, financial services, and other such professions. Many of these individuals burn out within the first five years on the job and look elsewhere for work that is more meaningful and satisfying, if lower paid. Adopting many of the same recruiting strategies as Teach For America, including the use of advertising signs in New York City subway trains and stations seeking individuals looking for intellectually challenging and meaningful work, TNTP developed stunningly effective mechanisms for recruiting thousands of individuals into city classrooms. All of TNTP's recruits had top college training, including many with degrees and expertise in math, science, and statistics — exactly the fields for which urban districts had trouble finding qualified teachers. ${ }^{16}$

Since its inception, TNTP has recruited and trained approximately 26,000 teachers through its Teaching Fellows and TNTP Academy programs, including roughly 1,780 in 2012. ${ }^{17}$ Its New York City Teaching Fellows program offers the best example of its scale: Since 2000 New York City Teaching Fellows has attracted more than 190,000 applications and supplied a total of 17,000 teachers to high-need New York City schools. ${ }^{18}$ The nearly 10,000 New York City Teaching Fellows currently working in the New York City school system represent approximately 11 percent of all New York City public-school teachers, including one in four math teachers and one in five science and special education teachers. ${ }^{19}$

In part because Teach For America and TNTP recruit during the spring for teaching positions beginning in the fall, the organizations can only provide training during the summer and, as a result, are severely criticized by the education establishment for providing their new recruits with insufficient preparation. These criticisms, however, ignore the fact that the bulk of the teachers these talented recruits replace are some of the less-effective teachers, as shown by multiple research studies over this past decade. ${ }^{20}$ What's more, the criticisms ignore the success these organizations have in recruiting some of the best talent in the country into urban schools, a probability that most in the education system - both public schools and colleges and universities - had not considered to be high. Indeed, more than half 
of Teach For America recruits remain in public education far beyond the initial two-year commitment, and a number of former recruits have launched new school strategies, including the Knowledge Is Power Program, or KIPP, Aspire, and other charter school models. ${ }^{21}$

As the 20th century was winding down and the 21st century was dawning, the landscape of public-school talent management could be best described as educational mismanagement. It was a mix of anemic and disjointed policies and practices that were characterized by ineffective recruitment programs, vacuous evaluation systems, the virtual giving away of tenure, promotion and dismissal based more on seniority than effectiveness, and pay linked to little, if anything, strategic to the system. These "personnel administration" approaches to talent management produced legions of ineffective teachers and principals in most urban and many rural districts that led to low student achievement, irrespective of curriculum, governance, or spending.

To be sure, the shoddy personnel administration practices did not typify every district, particularly many suburban districts. Further, several districts undoubtedly had solid programs in one or more of their human-resource management programs. And there were also multiple efforts created to improve the pre-service training and teacher-licensure systems. But the point is that education talent and its management was not at the top of districts' practice or policy agendas, and most human-resource management policies and practices were quite ineffective, with a focus on process rather than substance. As for Teach For America and TNTP, the two organizations that had figured out how to find and place top talent into urban and poor rural classrooms, there was scant acceptance, as well as widespread opposition to their programs and policies.

As the 21st century began, rumblings of change in approaches to educator talent started to emerge. An impetus for the change in schools' approach to talent came from the private sector, which recognized that the successful companies of the future would be in a global competition for top talent. ${ }^{22}$ This propelled the idea that talent mattered. The consensus was that the most successful companies would need to get very strategic about acquiring, developing, and retaining talent, which was seen as being key to implementing a company's strategic vision. Without top talent, it was surmised, the execution of strategic plans would not happen. 


\section{Rumblings of change in education- talent management}

As part of such strategic thinking, some companies began to restructure all of their talent management programs - recruitment, development, evaluation, promotion, dismissal, and compensation - around the competencies their workforces needed. Subsequent research showed that such a strategic approach to humancapital management led to higher levels of organizational performance. ${ }^{23}$ Further, just as the financial operations of companies had previously moved from an accounting approach to a more scientific approach to financial management, so too were there efforts to define a "science" of human-resource management with aligned metrics. ${ }^{24}$ In sum, numerous private-sector companies began to elevate talent management in their strategic agendas and created positions such as chief talent officer to signal the importance of this new focus.

Awareness and changes with respect to educator-talent management also began to emerge around a decade ago. In 2003 TNTP conducted a study of recruitment practices in several urban districts with a surprising conclusion: The inability to hire quality teachers and principals was largely a result of poor or nonexistent recruitment practices rather than that of the shortcomings of the applicant pool. ${ }^{25}$ TNTP's study found that most urban districts had substantial numbers of applicants for open positions but did not communicate with applicants when their applications were filed. In most cases, the districts did not begin to review applications until late August, when most quality applicants had already taken other jobs or had given up on the urban district, which meant that districts had to pick from the scant group of applicants still looking for a teaching job in late August or early September. The study recommended that districts move up the recruitment calendar, begin the application review process early in the year, communicate immediately with all applicants and continue communication with qualified candidates, take affirmative action to keep applicants with special skills - math and science teachers or male elementary school teachers, for example-continuously interested, and make job offers before the end of the school year. The TNTP study began to change the understanding about how urban districts could acquire top teacher and principal talent and that the ability to do so was mostly in their hands. 
Though Teach For America and TNTP operated almost as demonstration projects to show why talent management mattered and how talent could be recruited, additional approaches to better managing education talent were emerging such as new and more strategic approaches to teacher compensation. These new proposals sought to base annual pay increases on instructional practice and expertise, called knowledge and skills, and to augment them with school-based bonus programs triggered by student-achievement gains. The conferences and design seminars organized by the University of Wisconsin branch of the Consortium for Policy Research in Education, or CPRE, which started in 2000, began spreading knowledge about how new approaches to teacher compensation could be designed and accepted by teachers, as all the ideas it was proposing had been vetted by the two national teacher unions several years before the conference series began. ${ }^{26}$ These conferences and seminars showed how new compensation structures could be driven by metrics derived from the two prime strategic goals of the education: improved instructional practice and improved student achievement.

Likewise, the Teacher Advancement Program, created by the Milken Family Foundation, also began to address the pay issue, as did the Community Training and Assistance Center. But it was the Consortium for Policy Research in Education's work that laid the foundation in the late 1990s and in the very first few years of the 21 st century.

Another step toward nixing the old personnel administration programs and building more strategic approaches to education-talent management came from new ways of measuring instructional practice, or teacher effectiveness as it was later labeled. Three entities forged this new ground: the National Board for Professional Teaching Standards, the Connecticut Beginning Educator Support and Training Program, or BEST, and the work of the Educational Testing System incorporated into Charlotte Danielson's book on teacher evaluation. ${ }^{27}$ These systems actually provided substance as to how teachers could be evaluated, created systems to measure what teachers knew and were able to do, and provided multiple metrics of teacher effectiveness. Initially, reformers wanted the results to be used for a two-tiered licensure system, as well as for National Board recognition of practice to high and rigorous standards. But the Consortium for Policy Research in Education showed the metrics also could be used to operate new teacher salary structures for which major pay increases would be provided when a teacher's instructional practice met the standards of a higher level of performance, as indicated by the metrics of these new evaluation systems. ${ }^{28}$ 
A fourth rumbling action was the emergence of longitudinal data systems tracking individual student performance over time, as well as linking students to their classroom teachers. These systems allowed labor market economists and others to analyze factors linked to student-learning gains and to provide empirical evidence of "teacher effects." More specifically, these new data systems, largely the result of requirements of the federal No Child Left Behind Act, allowed researchers to show that teachers had very different and wide-ranging impacts on student achievement, with approximately 10 percent to 20 percent of teachers having extraordinary impacts (moving student learning two to three years during one academic year), another 10 percent to 20 percent producing anemic impacts with students actually dropping behind others in learning over an academic year, and with the vast bulk in the middle with modest achievement impacts. ${ }^{29}$

With most analysts using "value-added" metrics, study after study began showing that some teachers produced positive and others negative value added, with the implications that these results should be used to determine promotion and dismissal, pay increase and decrease, and tenure and no tenure decisions. ${ }^{30}$ Value added is a statistical procedure that identifies the degree to which a teacher produces above or below average gains in student performance after controlling for factors outside the teacher's control such as demographics. It is the most-used metric to show student growth.

With student-outcome data, scores of labor-market economists began studying multiple aspects of the teacher labor market, with the findings from all studies implying significant change in how teachers and principals should be managed. The studies documented:

- A lack of teacher quality in urban districts

- The disparate impact of teachers on student learning in districts and states across the country

- The outcomes of multiple initiatives to provide incentives to teachers in subject-area shortages

- The greater classroom effectiveness of Teach For America and TNTP teachers compared to teachers recruited from the lower-quality colleges and universities that had traditionally provided the bulk of new teachers to many urban districts

- Simulations of student performance increases that could be made by replacing ineffective teachers with effective teachers

- Many other aspects of the educator labor market ${ }^{31}$ 
A new research collaborative called the National Center for Analysis of Longitudinal Data in Education Research, or CALDER, became a focal point for this research. The implication was that value-added, or some other metric of teacher impact on student learning, should be a major element of new approaches to managing teachers and principals - metrics that were unavailable until these new longitudinal data systems emerged.

The practice community also weighed in as leadership in several urban districts began to address these talent issues in more strategic ways. Reform-oriented superintendents such as Arne Duncan, who served as the chief executive officer of Chicago Public Schools before being named secretary of the Department of Education in 2009; former New York City schools Chancellor Joel Klein, appointed in 2002; former Atlanta school Superintendent Dr. Beverly Hall, appointed in 1999; and others developed strategic partnerships with Teach For America and TNTP for new approaches to recruiting better teacher talent into their school systems. These same districts also partnered with a new organization, New Leaders for New Schools-since renamed "New Leaders"- to recruit a new breed of performanceoriented principals. Other districts partnered with the National Institute for School Leaders, or NISL, another national organization for recruiting and training a performance-focused group of principals. These partnerships implicitly acknowledged that the traditional higher-education pipelines these districts relied upon for teacher and principal talent were not good enough and that despite criticisms, the talent from Teach For America, TNTP, New Leaders, and the National Institute for School Leaders had a greater chance of being effective in classrooms and school buildings.

Other superintendents such as Carl Cohn with the Long Beach Unified School District, appointed in 1992; Tom Payzant with the Boston Public Schools, appointed in 1995; and Duncan, created new organizations — the Boston Teacher Residency and Chicago Academy for Urban School Leadership_-and/or partnered with their local higher education institution-California State University, Long Beach and the Long Beach schools — to prepare teachers with the skills needed to teach in their districts. Research showed these systems had considerable success in not only altering the talent landscape in their school systems but also in boosting student performance. ${ }^{32}$

In 2000 the Aspen Institute began networking these superintendent reformers through the Aspen Collaborative-a group of urban superintendents focused on improving educator talent and student achievement—-thus providing a forum for discussing and advancing these new approaches to acquiring and managing 
educator talent. Moreover, this group began using the terms "talent," "human capital," and "strategic talent management" as they addressed these human-resource management concerns, new policies, and reformed practices, which included the beginnings of using value-added measures in evaluation systems and new approaches to performance pay for teachers and principals. ${ }^{33}$

Simultaneously, several national foundations - including the Carnegie Corporation of New York, the Bill \& Melinda Gates Foundation, the Joyce Foundation, the Michael and Susan Dell Foundation, and several others that were more locally focused — concluded that educator talent and its management was a major education-reform issue and that resources needed to be deployed to help create the institutions and policies to build new talent-management systems. These foundations began to work in collaboration with one another to support these new approaches to talent acquisition and management in education and the organizations such as Teach For America, TNTP, and New Leaders, which were helping launch and execute these approaches.

These efforts were bolstered by the Broad Foundation - a group that focuses on improving urban public education - which began a program to train a new cadre of reform, performance, and strategic talent-management-oriented superintendents who generally did not come from traditional education organizations. Broad Foundation graduates quickly went on to lead urban districts in the wake of the aforementioned leading reformers in places such as Baltimore; Prince George's County, Maryland; Los Angeles Unified; and Gwinnett County, Georgia, to name a few. The Broad Foundation also created a program called Broad Residents for individuals who had law degree, master's degree in business, and/or public policy degrees to take more middle-level management positions in central offices of urban districts. Many Broad Residents ended up in human-resource management departments and several were quickly elevated to the newly created positions of chief talent officer and chief human capital officer, taking key positions on the superintendent's cabinet.

The George W. Bush administration also created the Teacher Incentive Fund with hundreds of millions of dollars provided for urban districts and states to create new teacher-compensation elements, providing incentives for teachers in subjectarea shortages such as math and science to teach in high-poverty schools, and to improve student performance beyond traditional gains over an academic year. 
In sum, the sleeping giant of personnel administration began coming out of its hibernation in the first years of the 2000s with huge changes being made in multiple areas - recruitment, evaluation, compensation, and more — by many individual actors, organizations, and foundations across the country. The reform rumblings and collaboration among the national foundations, the superintendents in the Aspen Collaborative, and other reform groups and organizations-Teach For America, TNTP, New Leaders, and the Consortium for Policy Research in Education-began coalescing into a wave of change over talent and its management, which more leaders were conceding was critical to the successful implementation of all other education reforms.

These changes were not without controversy. Not everyone sanctioned the approaches to talent recruitment by Teach For America, TNTP, or New Leaders - none of which directly used the traditional university-training channels. In addition, not everyone wanted to use value-added measures in teacher evaluations or even use the new evaluation metrics for consequential decisions for teachers. The Broad Foundation-trained superintendents were not welcome in every urban district. New approaches to teacher compensation were not uniformly embraced. And it was not just the teachers unions that raised objections to these reforms - so too did the leaders of many of the other education organizations at the national and state level, as well as members of the American Education Research Association and the National Academy of Education.

But these examples reflect the changes that began to occur during the early years of this century-they occurred across the entire country, had the financial backing of many of the largest foundations, including the emerging and dominant Gates Foundation, and were addressing what was becoming recognized as a core education reform issue: educator talent and its strategic management. 


\section{Educator-talent management reform solidifies}

About six years ago, these multiple and somewhat disparate initiatives in educatortalent management began to solidify, even though controversy surrounded nearly every individual initiative.

Probably the "lighting rod" action suggesting that these new ideas about talent management in education were taking root was the summer 2007 appointment of Michelle Rhee as the chancellor of the Washington, D.C., Public Schools. A former Teach For America teacher, founder and then-chief executive officer of TNTP, and never having been a school administrator-let alone a top central office staff administrator-Rhee took the helm of the Washington, D.C., school district and immediately began implementing change. She partnered with Teach For America, TNTP, and New Leaders for teacher and principal recruitment and also moved up the district's recruitment calendar, as she knew many talented individuals had historically applied for positions with the district but accepted other posts because the district failed to contact them in a timely manner.

Additionally, Rhee closed low-performing schools and restructured the school budget. She put art, music, and physical education teachers into elementary schools so that teachers at all levels would have time during the regular school day for collaborative work using student data. She hired a national expert on professional development, who was particularly skilled in working with teachers to help them use student data to modify lesson plans and instructional units. Within a year, Rhee had created a new teacher-evaluation system, with 50 percent of teacher evaluation based on a measure of instructional practice and 50 percent on student achievement, and began negotiating to use it in a new pay system for teachers, as well as a basis for terminating ineffective teachers. ${ }^{34}$ The reform package was a new strategy to acquire better talent, retain only the most-effective teachers in the district's lowest-performing schools, and move out those instructors who were ineffective. In short, she put talent and its strategic management as the lead item on her reform agenda. 
These moves, however, were met with controversy. The national American Federation of Teachers union involved itself in district negotiations and subsequently sued the Washington, D.C., Public Schools to prohibit the use of the new evaluation system to manage teachers. Rhee left the chancellor's post after only three years when her mayoral supporter-former Mayor Adrian Fenty-was not re-elected to office in part because of the "radical" nature of Rhee's reforms. But the key central office staff she recruited remained, and they continue the district's talent reforms.

Jim Kelly, the founding president of the National Board for Professional Teaching Standards, along with the author of this report, created the Strategic Management of Human Capital Task Force, with support from the Carnegie Corporation of New York, and the Ford, Gates, and Joyce foundations. The task force included leaders from most of the national education organizations-National Education Association, American Federation of Teachers, American Association of School Administrators, Council of Chief State School Officers, Council of Great City Schools, National Association of Secondary School Principals, American Association of Colleges for Teacher Education, the superintendents mentioned in the previous section, the presidents of Teach For America, TNTP and New Leaders, and several other prominent education and political thinkers and leaders, including then-Gov. Tim Pawlenty (R-MN), who chaired the task force, and former Gov. Jim Hunt (D-NC).

The purpose of this effort was to prominently place a strategic approach to education-talent management on the nation's education policy and practice agenda. A first effort was publishing case studies of new and successful approaches to talent acquisition and management in the leading talent-reform districts-Boston, Chicago, Fairfax County, Virginia, Long Beach, California, and New York Cityand of the national talent development and recruitment organizations-Teach For America, TNTP, and New Leaders. ${ }^{35}$ The project held national meetings profiling these efforts, outlined what strategic talent management in education should be, ${ }^{36}$ created networks of state and local districts engaging in such reforms, and issued talent management reform documents. ${ }^{37}$

In the second year of the Strategic Management of Human Capital Task Force, though launched much earlier, TNTP released its comprehensive study of teacher-evaluation systems in urban districts around the country. Titled "The Widget Effect," the study found that the teacher-evaluation systems studied identified upward of 98 percent of all teachers were satisfactory or even accomplished, even when student performance was dismal. ${ }^{38}$ The study received national atten- 
tion and underscored the vacuous nature of typical teacher-evaluation systems, which did not treat teachers differently by their documented effectiveness but as "widgets" irrespective of their success in the classroom. The study concluded by stating that key to changing how talent was managed in education were more robust evaluation systems that arrayed educators on a multilevel scale of effectiveness. Without such metrics, the study argued, it would be hard, if not impossible, to strategically manage - tenure, dismiss, reward, and compensate-teachers and principals, or produce a fair distribution of effective teachers across all schools.

These efforts were fortuitously and significantly bolstered in late 2008 by the election of President Barack Obama, especially when he appointed then-Superintendent of Chicago Public Schools Duncan as U.S. Department of Education secretary. ${ }^{39}$ Together, these two national leaders placed all the key elements of strategic management of education talent on the national agenda, first through four key assurances governors made in 2009 when accepting the first package of general stimulus dollars, and second through the Race to the Top program. ${ }^{40}$

States applying to win funds through Race to the Top were required to describe how they would change recruitment policies, redesign teacher evaluation to include evidence of teacher impact on student learning as a significant element, alter tenure stipulations to be based on teacher effectiveness, create performancepay systems, and include a talent renewal aspect for school turnaround strategies. Race to the Top was followed by the Department of Education's School Improvement Grants program that had strategic talent management at its core, and then was an extension of the Teacher Incentive Fund program.

For the first time, these federal actions provided a broad, comprehensive, and coherent policy umbrella for how talent should be managed in education by aligning all key elements from preservice training to district recruitment, evaluation, tenure, dismissal, and pay around metrics of teacher and principal effectiveness. In this process, the focus of the No Child Left Behind Act on "highly qualified" teachers, which had emphasized credentials, shifted to a focus on "highly effective" teachers and principals as assessed through new, robust teacher and principal evaluation systems that included measurable results.

This solidifying of the change in education-talent management was accompanied by the rise of new national "experts" on these issues. When writing articles on this topic, reporters at_Education Week, the national newspaper devoted to covering education, began to contact and quote people such as Tim Daly, president 
of TNTP, and Kate Walsh and Sandi Jacobs, both with the National Council on Teacher Quality, along with talent-management-reform superintendents. All of them suggested, among other new policy positions, that educator recruitment had to change for urban districts; that teacher-evaluation systems needed reform and to include student data as a significant aspect of such evaluations; that performance pay was needed to insure that the most effective teachers were paid what they were worth; and that state policies on licensure, tenure, evaluation, and pay needed reform to bolster these local practices.

Further, articles in Education Week and elsewhere about management in education began to echo all of the themes listed above and argue that all programs of talent management-licensure, recruitment, selection, placement, evaluation, tenure, promotion and dismissal, and compensation — needed to be aligned and managed around a set of effectiveness metrics produced by new evaluation systems. This perspective was reinforced by a new book, Strategic Management of Human Capital In Education, on what strategic management of human capital in education could be, ${ }^{41}$ with the hope that the book would replace the more traditional "personnel administration" books used in university-based administrator-training programs.

But as policy changes multiplied and were reflected across the country by related changes in local district practice, resistance strengthened. Some claimed that these new initiatives were top down and were being forced onto teachers, principals, and education systems, and argued that more collaboration was needed to hone policy and practice. Others opponents claimed that it was unfair to hold teachers accountable for student-performance growth by using student-learning gains in new teacher evaluation systems. Critics emerged over the metrics being used to assess student growth, arguing that the errors associated with value added or other measures of growth were too large to use for consequential decisions for teachers and administrators. Yet others insisted that the pace of change should slow as the Great Recession had eroded education budgets, eliminating the money needed to fund these new efforts. And finally, many in the education system - both teachers and administrators - saw this push for "performance management" as an unwarranted critique of the education system blaming it and its key workers-teachers and principals - for the lack of student-performance gains across the country. In short, multiple pockets of resistance existed across the country just as these new approaches to talent management seemed to be solidifying. 


\section{A new world of talent management in education: Putting strategic talent management at the center of education policy and practice}

Despite resistance, this new world of strategic talent management in education has developed a firm foundation built upon the initiatives just described. There has been substantial, widespread, and positive state response to Race to the Top. This ongoing competitive grant program offered substantial sums of money to states that pledged to design and implement sweeping changes in policy and practice on the talent management front. But only a small number of states would be funded to do so. Nevertheless, more than two-thirds of the states submitted Race to the Top proposals. States controlled by Democrats and Republicans won the grant funding, and virtually no state complained that the funding was distributed unfairly. ${ }^{42}$

Further, the state proposals promised:

- Changes in licensing systems to allow Teach For America, TNTP, New Leaders, and other nontraditional training program recruits to obtain initial licenses to practice

- Creation of longitudinal data systems that linked students to teachers and schools so growth metrics for teachers and schools could be calculated

- Revised teacher and principal evaluation systems that used student-growth measures as a substantial aspect of the evaluation

- Use of the new evaluation metrics for educator tenure, promotion, dismissal, and performance pay structures

- Turnaround strategies for low-performing schools that allowed for significant replacement of teacher and principal talent in the process

- Expanded school choice with fewer limits on the number of charter schools 
Such promised change in policy and practice was hardly imaginable a decade ago, so the positive response to the requirements of Race to the Top was quite stunning.

These changes were supported by a group of Democrats committed to education reform, including former Govs. Ted Strickland $(\mathrm{OH})$ and Phil Bredesen (TN) -a first-round Race to the Top winner-and current Gov. Andrew Cuomo (NY). An organization called Democrats for Education Reform, supported and urged many state lawmakers to push similar changes in state legislatures. ${ }^{43}$ Also, the Center for American Progress began issuing a series of reports bolstering these same efforts. ${ }^{44}$ What's more, Republicans also bought into this agenda, including Gov. Chris Christie (R-NJ) and former Florida Gov. Charlie Crist (who was a Republican at this time). In short, education talent-management reform garnered bipartisan support at the levels where education policy was most often designed and where enforcement of such policies was likely to reside.

The strength of state support for these comprehensive and ambitious changes in education talent management was again displayed in 2012 through state responses to the requirements for waivers from No Child Left Behind accountability requirements. To earn a waiver, a state not only needed to design new accountability systems for schools and districts that would be linked to student achievement in the Common Core curriculum standards, but states were also required to present proposals to change all elements of human resource management in education, including new teacher and principal evaluation systems and the use of the metrics from these systems for teacher tenure, placement, distribution, promotion, dismissal, and compensation. Despite these rigorous requirements, most states requested waivers, promising talent-management reforms without the incentive of additional money they might have received from Race to the Top, School Improvement Grants, or Teacher Incentive Fund programs.

Today about 40 states and District of Columbia are designing, piloting, or implementing new teacher and principal-evaluation systems. For teachers, the reforms include ambitious efforts to measure a teacher's instructional practice and include evidence of student-learning gains that comprise up to 50 percent of the overall evaluation score. ${ }^{45}$ Though many states are facing challenges in these development efforts - the sizable costs of direct observations of teachers, for example - they continue to move forward in designing and implementing these systems.

Moreover, Ohio intends to use the metrics in a multitiered licensure system. To be awarded tenure, teachers will need to demonstrate that their effectiveness has 
risen to a level above that needed for the professional license. Other states are considering similar efforts to use the effectiveness metrics for multitiered licensure systems, with a beginning level for new teachers, a higher level for the professional license, an even higher level for tenure, and then perhaps one to two levels above that for advanced practice. States and districts are also designing new salary structures driven largely by these effectiveness metrics, which will link teacher pay levels to effectiveness levels, thus aligning pay with performance.

The 2012 expansion of the Teacher Incentive Fund program required districts to first create "a vision of effective instruction and its improvement" and then to design an overall talent-management program — recruitment, placement, evaluation, tenure, promotion and dismissal, and compensation - within which new approaches to performance pay for teachers and principals would fit strategically. ${ }^{46}$ This more comprehensive approach to performance pay again enshrined a comprehensive and strategic approach to educator talent management as a centerpiece of federal policy.

The national foundations gave further impetus to these federal reforms. In an effort to provide existence proofs for this new foundation of talent management, the Bill \& Melinda Gates Foundation provided large sums of money to four education systems - Hillsborough County, Florida; Memphis, Tennessee; Pittsburgh, Pennsylvania; and a consortium of charter school operators in California-to design and implement all of these related talent-management reforms to document how it can be done at the district level.

In addition, in 2012 several foundations helped create the Urban Schools Human Capital Management, designed to provide technical assistance to many other cutting-edge urban districts-Baltimore; Boston; Denver; Gwinnett County, Georgia; New York; and Prince George's County, Maryland; among others_-that are all similarly engaged in robust and comprehensive talent management reforms of recruitment, evaluation, tenure, promotion, distribution, and compensation. ${ }^{47}$

There is considerable action on all these items in close to three-fourths of the states and in scores of local districts - mostly urban districts where the human-capital management systems were significantly broken and in need of major change.

Moreover, talent-management reformers continue to take on leadership positions in a number of states and districts. Deborah Gist, who worked with Michelle Rhee as the state superintendent of education in Washington, D.C., soon thereafter became Rhode Island commissioner of elementary and secondary education, 
and began sponsoring reforms similar to those in the District of Columbia. ${ }^{48}$ Kevin Huffman, the commissioner of the Tennessee Department of Education, is a former executive for Teach For America and the first former Teach For America corps member to become a chief state school officer ${ }^{49}$ Another former Teach For America corps member, Cami Anderson, was named superintendent of Newark Public Schools in 2011, where she recently negotiated a new teacher contract with a new evaluation system and pay package similar to the system in Washington, D.C. Public Schools. ${ }^{50}$ Further, there are growing numbers of former Teach For America teachers who have gone on to become principals. Teach For America and TNTP have significantly expanded their operations to include more cities, as well as recruiting up to four times the numbers of teachers as compared to five years ago. ${ }^{51}$

Adding to this developing foundation, the two national teachers unions are working publicly and behind the scenes to move these reforms forward. The National Education Association, which previously had a policy that prohibited the use of student test scores in teacher evaluations, revised its policy and now encourages districts and states to design new systems that use such data. The American Federation of Teachers, though visibly prominent in opposing the Rhee-designed reforms in Washington, D.C., is working in many local districts to more collaboratively design talent-management reforms, including evaluations that include student data and to use these results for placement, promotion, tenure, and compensation.

Despite the developing strong foundation for strategic talent management in education, the road forward is not without its bumps. The Chicago Teachers Union, an affiliate of the American Federation of Teachers, went on strike for nearly two weeks in the fall of 2012, where a key issue was teacher evaluation and the use of student scores in the evaluation system. ${ }^{52}$ The president of the Chicago Teachers Union led a reform backlash movement at the 2012 annual meeting of the American Federation of Teachers, criticizing its president for working on and supporting these initiatives in other school districts. Tony Bennett, a talent-management reformer and superintendent for public instruction in Indiana, was voted out of office in November 2012, due in large part to his support for these reforms - although in early December he was appointed to be Florida's new education commissioner, a state leader in school talent-management reforms. Similarly, education-reform laws that included talent management were voted down in Idaho and South Dakota in the November 2012 elections. And teachers in Seattle walked out in early 2013, opposing the requirement to administer new benchmark assessments that would be used in teacher-evaluation systems. To be clear, the path forward when it comes to school talent-management reforms will be one of bumps, if not potholes. 
Nevertheless, a foundation for change is being built, the landscape of talent management in education has changed, and it is highly unlikely that these changes will be completely undone. Most states are revamping teacher and principal evaluation systems, using a combination of measures of practice and evidence of impact on student-learning growth — and sometimes student surveys. And new research shows that such metrics can be valid, stable, and reliable. ${ }^{53}$ States intend to use the metrics from the new systems for decisions regarding tenure, promotion, compensation, and perhaps for multitiered licensure systems as well. Many districts across the country are creating local policies and practices that mirror and implement state initiatives, showing that it is not just the policy community but also practitioners moving forward on these agendas.

Clearly, the goal is to dramatically transform the backwaters of what have been "personnel administration" activities into strategic human-capital-management systems in education for which all key programs - recruitment, placement, distribution, development, evaluation, tenure, promotion, dismissal, and compensation-are aligned around metrics that assess instructional effectiveness and student-learning growth - the twin key goals of today's education system, the latter being the prime goal and the former being the means to that goal.

Though such transformation in these key elements of education systems was deemed impossible nearly a decade ago, as Jim Kelly, the founder and first president of the National Board for Professional Teaching Standards, wrote in 2011, "America is able to make such major transformations despite not having a central educational governing system."38 



\section{Challenges ahead}

Although it appears that talent-management systems in education are changing for the better, one must not assume that everything can or will happen overnight. Not only is there the resistance mentioned above, but there are other significant challenges as well.

One such challenge is the cost of the new evaluation systems. Creating the new student data systems and calculating the different growth measures is pretty straightforward - though there are arguments concerning the best growth metrics to use. But the process required to gather evidence of instructional practice is much more daunting. Most states today require districts to conduct multiple live observations of teachers and such approaches require either hiring large numbers of observersHillsborough County, Florida, for example, hired about 250 teachers to conduct such observations on a full-time basis - or burdening principals with such tasks, which will consume large percentages of their time and erode their ability to lead schools. Both approaches are costly and many argue neither is sustainable in large part because both approaches require significant ongoing training to ensure that the observations produce valid and reliable results for teachers.

The hope among many is that education systems will adopt video technologies to gather such evidence as a way to rein in costs. Teachscape is one provider of a modest cost system. ${ }^{55}$ Though each video episode must be scored to appropriate rubrics, trained experts, including possibly accomplished teachers, could do the scoring and be paid on a piecemeal basis. Clearly, the time allocation and dollar cost of the evaluation systems need to be modest.

Another challenge is the propensity of states to decentralize to districts many of the specific design elements of the new evaluation systems, including determining the "cut points" that determine whether an individual is ineffective, developing effective, effective, highly effective, or extremely effective. Due in part to the strong equity culture that permeates most school systems, the disinclination to make distinctions among teachers or principals on the basis of their effectiveness has resulted in many 
districts setting cut points that make most teachers effective or higher, even when they produce below average improvements in student learning. Consider the case of the Florida Department of Education, which recently reported that more than 96.5 percent of teachers in the state have been identified as effective or above. It should be noted, however, that the percentage of students performing at the proficient or advanced levels is nowhere near as high. Similarly, in Michigan and Tennessee, administrators rated 98 percent of teachers as effective. In Georgia 94 percent of teachers received favorable ratings. ${ }^{56}$ Likewise, in these states too, student-achievement rates come nowhere near these lofty levels. Clearly, considerable recalibration is likely to be required in order for the new system to provide meaningful metrics that can aid in the strategic management of the teachers and principals evaluated.

A third challenge is related to the pressure from the education establishment to make the initial entry into teaching more rigorous. Hiking requirements for admission into teacher-training programs is a solid strategy; it would weed out ineffective talent, which has been the major source of new talent for many urban systems as discussed above. But caution should be exercised concerning efforts to hike requirements for the initial teaching license, as compared to the requirements for the professional teaching license, which is usually conferred after two to four years of teaching. Standards for the professional license should be very rigorous, allowing only those who show they meet the effectiveness standards needed to become fully licensed teachers.

But efforts to create an assessment similar to the bar exam, which is used by the legal profession, to afford entry into the teaching profession should be viewed with caution. Such an exam would probably eliminate most of the talent recruited by Teach For America and TNTP since the summer training of their recruits would unlikely be sufficient for the new recruits to pass a rigorous assessment of practice. And those organizations' successful efforts to get top talent into urban classrooms would be undercut. Further, Teach For America provides its recruits with intensive training and coaching during their first two years of teaching, something some urban districts provide that most unfortunately do not. This coaching ensures that the new recruits quickly acquire an array of effective instructional practices. Likewise, TNTP has instituted one of the first rigorous precertification screens for teacher certification. During 2011 and 2012 approximately 2,000 teachers trained by TNTP were required to demonstrate effectiveness in the classroom - as measured by a combination of classroom observations, student surveys, principal ratings, and where possible, student academic growth data-in order to be recommended for state licensure. Research shows that the Teach For 
America and TNTP recruits produce little, if any, decrease in educational productivity and oftentimes significantly outperform individuals who have come through traditional higher education programs.$^{57}$ It would be foolish to establish requirements that cut off this flow of talent into urban systems.

Certainly, it can be argued that the initial teaching license should be based more on rigorous assessments of content knowledge and that the rigorous "bar exam," which would assess instructional expertise and impact on student learning, should be used to confer the full professional license and be required of every novice teacher at some point after three to five years of teaching. Of course, given this perspective on initial entry it could be argued, "Why not make entry difficult at every point?" There are ways to ensure that only top talent meets initial entry standards, thus supporting the talent acquisition strategies of Teach For America and TNTP, while also ensuring that only demonstrably effective teachers earn the full, professional license and then tenure, whatever their pathway into the profession.

Finally, as the resistance in Seattle reflects an aversion on the part of educators to adopt assessments just for evaluation purposes; there is the challenge to embed all of these talent management efforts - as the Teacher Incentive Fund regulations require - in a vision of effective instruction and academic improvement, which are the focus of the Common Core State Standards Initiative. The education system needs to keep its prime focus on what it takes to make all students college and career ready. Accomplishing that goal certainly requires effective teacher and principal talent and it will require not only new summative assessments aligned with the Common Core State Standards, but also short-cycle assessments that teachers need for instructional improvement and many other elements. The assessments used in teacher evaluation should flow from instructional practices shown to be effective in student learning. The improvement process and not the evaluation system should drive educator actions-evaluation should simply determine whether the improvement process works - and for the purposes of this paper, whether the talent-management system is producing effective teachers and administrators.

There are other challenges as well, but unless the education system continues to recruit a significant portion of the best and brightest - those graduates with the top academic scores and ability_-into our schools — as the top academically performing countries do internationally_and then ensure that the necessary evaluation systems, providing truly meaningful metrics, are developed and operate smoothly at an affordable cost, the overall goals of strategic talent management will be difficult to attain. 



\section{Reasons underlying monumental changes in talent management}

Last, it is fair to ask why such major changes in talent and its management have occurred so quickly. Though there is no definitive answer to this question, the three factors detailed below might help to explain this phenomenon.

The first factor is related to the fact that the message coming from the national education talent organizations-Teach For America, TNTP, and New Leaders, for example - that "talent matters" became accepted across wide spectrums of the education and policy communities - and bolstered by private-sector organizations that are also focused on talent. This perspective was in contrast to the education system that believed that poor student achievement was primarily the result of some combination of lack of curriculum rigor, insufficient funding, large class sizes, anemic professional development, inadequate parent support, too little collaboration, or the misguided belief by some that children from low-income families simply could not learn at higher levels. The national talent organizations argued that while these issues were not insignificant, the core issue was insufficient talent—there were just too few smart and capable people in the most challenging schools who would relentlessly work to make sure that all students learned.

To make a football analogy: John Harbaugh, the coach of the 2013 Super Bowl Champion Baltimore Ravens, could not take a team comprised of Division III college players to the Super Bowl; a team of such players, individuals who might have real skills, do not have the talent to succeed in the NFL regardless of the level of coaching, quality of equipment, or strength of fan support. Similarly, teaching in urban and poverty-stricken rural schools is difficult and intellectually challenging work. It takes the most talented individuals in the country to succeed in these school environments, working relentlessly every day to succeed. Yes, these individuals need instructional expertise, but as a raw foundation they need the intellectual power to figure out how best to organize their classrooms and teach the curriculum effectively to all students - most of whom come to school every day with multiple issues, social and otherwise, that make learning challenging. 
Fortunately, the national talent organizations have figured out how to recruit the best and the brightest young talent in the country into the most challenging schools, which is step one in making these schools successful and giving students the best chances to learn. It did not hurt that at about the same time these national talent organizations were created, the importance of talent was also being recognized in the corporate world, though it took more than a decade for the importance of talent per se to be recognized as a core solution to improving our schools.

Two additional characteristics of these national talent organizations should be also noted. The first being that these organizations are national in focus, as compared to colleges and universities - the traditional pipelines for teachers and principalswhich are at best regional, and more often than not, local, sources of talent. Thus, the national talent organizations have the advantage of focusing their talent-recruitment effort nationally and at scale while at the same time concentrating on meeting the needs of the places most lacking educator talent—high-poverty urban and rural school districts. And the second trait common to national talent organizations is the fact that they are not universities and as such they don't have to produce reams of research proving and documenting their conclusion that the lack of talent is a key factor in the modest levels of success coming from education reform.

The second factor explaining why talent management now tops the education policy agenda is that the talent perspective has been sanctioned by several influential education reformers - progressive superintendents, governors, and legislators mentioned previously_-individuals who have attracted national press coverage as they acted to redress educator talent shortcomings. Further, these state, local, and school leaders were then reinforced in their reform beliefs by a newly elected president-Barack Obama - who agreed with their diagnosis and their prescription. Once in office, the president wasted little time in appointing Arne Duncan as U.S. secretary of education, who as the superintendent of the Chicago Public Schools adopted the talent agenda for the district. Such political sanction at the highest level of this new approach to education reform was powerful—both symbolically and substantively. ${ }^{58}$

It should also be noted that the leaders mentioned above were not the only ones who gave substantive and symbolic support to the importance of talent as a key to education reform. Leadership and support also have been provided by thousands of former Teach For America teachers who now work in leadership positions, and in those posts sanction the same approach to educator talent and its management. Teach For America has an annual national conference for its corps members who 
have left teaching, but who are working locally_in parent/teacher organizations, as members of local school boards, as advisors to state governors, as leaders of civic groups such as the Rotary, and in similar state organizations - to advance education talent reform. To encourage this type of involvement, Teach For America now provides leadership training, equipping their recruits and alumni with highly detailed information about the workings of education systems so they can advocate for and support even more ambitious versions of education improvement, including helping to meet the core issue of first acquiring top talent.

Though these reform-minded individuals are both Democrat and Republican, the bulk are Democrats and as such have created a new cadre of reformers within the Democratic caucus that fully embraces this different view of education reform.

A third factor behind this shift to talent-management reform undoubtedly has been the testing regime of the No Child Left Behind Act, which requires districts to test students in reading and math every year for grades three through eight and once during grades 10 through 12 and report the results not only for all students, but also for "subgroups" of students, including those from ethnic and racial, non-English-speaking, and poverty backgrounds. The tests have not only documented much lower achievement levels in urban and poor rural districts, but also wide achievement gaps between majority and higher-income students, and those of ethnic minority, lower-income, and non-English-speaking backgrounds. When states began to link students with the teachers who taught them the tested subjects, these longitudinal data systems allowed analysts to document wide differences in learning growth across classrooms, with many urban and poor rural classrooms showing the lowest level of growth. These results combined heightened public interest in the factors underlying these achievement deficiencies, as well as differential teacher effects, reinforcing the emerging interest in educator talent as a core problem.

Finally, these talent reformers soon garnered support of the nation's largest private foundations, as well as new foundations created by successful tech entrepreneurs - the Michael \& Susan Dell Foundation, for example-all of which supported the idea that talent was key and that performance-based management characterized the most effective organizations, including in their human-capitalmanagement systems as well. Though other factors have undoubtedly contributed to the quick ascension of talent-management reform to the top of the education policy and practice agendas, the above are strong contributors. ${ }^{59}$ 



\section{Conclusion}

There is a clear understanding across policy communities that the aspirations of current education reforms, especially the goal of preparing all students to be college and career ready through effectively teaching curriculums that are aligned with the Common Core State Standards Initiative, can only be attained if the talent in our classrooms and school buildings is up to the task. Likewise, there is an acknowledgement that there are too few smart and capable people staffing our most challenging schools - specifically, schools serving poor urban and rural communities. The upshot: Talent truly matters.

This undeniable fact is the impetus for the rapidly shifting landscape of humancapital management that is impacting all stages of the educator pipeline. The good news is that talent management in education is changing in strategic ways and the foundation that has been built through both public and private initiatives makes it highly unlikely that it will return to the broken and disjointed personnel administration systems that characterized education just a decade ago. 

Allan Odden is the director of Strategic Management of Human Capital, or SMHC, a project of the Consortium for Policy Research in Education. He is also professor emeritus of educational leadership and policy analysis at the University of Wisconsin-Madison and co-director of the Consortium for Policy Research in Education, a consortium of the University of Wisconsin-Madison, University of Pennsylvania, Harvard University, University of Michigan, Northwestern University, Teachers College at Columbia University, and Stanford University. Allan was formerly a professor of education policy and administration at the University of Southern California. He is an expert on the strategic management of human capital in education, teacher compensation, teacher evaluation, education finance, school turnaround, effective resource allocation and use, resource reallocation, schoolbased management, and educational policy development and implementation. 

1 Thomas J. Kane and Douglas O. Staiger, "Estimating Teacher Impacts on Student Achievement: An Experimental Evaluation."Working Paper 14607 (National Board of Economic Research, 2008); Jonah E. Rockoff, "The Impact of Individual Teachers on Student Achievement: Evidence from Panel Data," American Economic Review 94 (2) (2004): 247-252; P. Sander Wright, Sharon P. Horn, and William L. Sanders, "Teacher and Classroom Context Effects on Student Achievement: Implications for Teacher Evaluation," Journal of Personnel Evaluation in Education 11 (1) (1997): 57-67.

2 L. Dean Webb and Scott Norton, Human Resources Administration: Personnel Issues and Needs in Education (New York: Allyn and Bacon, 2009).

3 Phil Schlechty and Victor Vance, "Recruitment, Selection and Retention: The Shape of the Teaching Force,". The Elementary School Journal 83 (4) (1983): 480-487. Though the measures of quality were primitive-fully credentialed or not, or SAT and ACT scores-most agreed that although rough, the measures were sufficient to document teacher quality decline.

4 Don Boyd and others, "The Narrowing Gap in New York City Teacher Qualifications and its Implications for Student Achievement in High-Poverty Schools" (Washington: The Urban Institute, 2008); National Commission on Teaching and America's Future, "What Matters Most: Teaching in America" (1996).

5 Michelle Rhee, Radical: Fighting to Put Students First (New York: HarperCollins, 2013).

6 Personal communication with Michelle Rhee, summer 2007.

7 Kenneth D. Peterson, Teacher Evaluation: A Comprehensive Guide to New Directions and Practices (Thousand Oaks, CA: Corwin Press, 2000)

8 Webb and Norton, Human Resources Administration.

9 Tenure is used as a generic term for tenure, continuing contract status, due process, etc.

10 See the annual reports from the National Commission on Teacher Quality, available at http://www.nctg.org.

11 Allan Odden and Carolyn Kelley, Paying Teachers for What They Know and Do: New and Smarter Compensation Strategies to Improve Schools (Thousand Oaks, CA: Corwin Press, 1997).

12 National Commission on Teaching and America's Future, "What Matters Most"

13 Donna Foote, Relentless Pursuit (New York: Knopf, 2008); Scott Eidler, "Deferring Six Figures on Wall Street for Teacher's Salary," DealBook, January 2, 2013, available at http://dealbook.nytimes.com/2013/01/02/deferringsix-figures-on-wall-street-for-teachers-salary/.

14 Teach For America, "Where We Work," available at http:// www.teachforamerica.org/where-we-work; Eidler, "Deferring Six Figures on Wall Street for Teacher's Salary."

15 Teach For America, "Retention Report" (2010), available at http://www.teachforamerica.org.
16 Anabel Aportela and Michael Goetz, "Strategic Manage ment of Human Capital: The New Teacher Project" (Madison, Wl: Consortium for Policy Research in Education, 2008).

17 TNTP, "Teaching Fellows," available at http://tntp.org/ what-we-do/training/teaching-fellows.

18 NYC Teaching Fellows, "Our Impact," available at https:// www.nycteachingfellows.org/purpose/impact.asp (last accessed March 2013).

19 Ibid.

20 Gary Henry and others, "Portal Report: Teacher Preparation and Student Test Scores in North Carolina" (Chape Hill, NC: University of North Carolina, Carolina Institute for Public Policy, 2010); George H. Noell and Kristin A. Gansl, "Teach for America Teachers' Contribution to Student Achievement in Louisiana in Grades 4-9: 2004-2005 to 2006-2007" (Baton Rouge: Louisiana Department of Education, 2009), available at http://www. nctq.org/docs/TFA Louisiana study.PDF; Tennessee Higher Education Commission "2010 Report Card on the Effectiveness of Teacher Training Programs" (2010); Zeyu Xu, Jane Hannaway, and Colin Taylor, "Making a Difference? The Effects of Teach for America in High School" (Washington: The Urban Institute and CALDER, 2008), available at http://www.urban.org/UploadedPDF/411642_Teach_America.pdf

21 Teach For America, "Retention Report."

22 Edward E. Lawler III, Talent: Making People Your Competitive Advantage (San Francisco: Jossey-Bass, 2008).

23 T. Russell Crook and others, "Does Human Capital Matter? A Meta-Analysis of the Relationship Between Human Capital and Firm Performance," Journal of Applied Psychology 96 (3) (2010): 443-456.

24 John Boudreau and Peter Ramstad, Beyond HR: The New Science of Human Capital (Cambridge, MA: Harvard Business School Press, 2007).

25 Jessica D. Levin and Meredith Quinn, "Missed Op portunities: How We Keep High-Quality Teachers Out of Urban Classrooms" (New York: The New Teacher Project, 2003).

26 Odden and Kelly, Paying Teachers for What They Know and Do.

27 Andrew Porter, Allan Odden, and Peter Youngs, "State Leadership in Teacher Licensure," Educational Policy 17 (2) (2003): 217-236; Charlotte Danielson, Enhancing Professional Practice: A Framework for Teaching (Alexandria, VA: Association for Supervision and Curriculum Development, 2007).

28 Odden and Kelley, Paying Teachers for What They Know and Do.

29 Sander Wright, Horn, and Sanders, "Teacher and Classroom Context Effects on Student Achievement"; Brian Rowan, Richard Correnti, and Robert Miller, "What Large-Scale, Survey Research Tells Us About Teacher Effects on Student Achievement: Insights from the Prospects Study of Elementary Schools," Teachers College Record 104 (8) (2002): 1525-1567. 
30 Douglas Harris, Value-Added Measures in Education (Cambridge, MA: Harvard Education Press, 2011).

31 Eric A. Hanushek, "Teacher Deselection." In Dan Goldhaber and Jane Hannaway, eds., Creating a New Teaching Profession (Washington: Urban Institute Press, 2008). See also various analyses and research reports from CALDER, available at http://www.caldercenter.org.

32 Julie Koppich and Connnie Showalter, "Strategic Management of Human Capital: A Cross Case Analysis of Five Districts" (Madison, Wl: Consortium for Policy Research in Education, 2008). For more information, see Strategic Management of Human Capital cases, available at http://www.smhc-cpre.org.

33 Rachel Curtis and Judy Wurtzel, Teaching Talent: $A$ Visionary Framework for Human Capital in Education (Cambridge, MA: Harvard Education Press, 2010).

34 Sam Dillon, "A School Chief Takes on Tenure, Stirring a Fight," The New York Times, November 12, 2008, p. A1.

35 "Strategic Management of Human Capital," available at http://www.smhc-cpre.org (last accessed March 2013).

36 Allan Odden and James Kelly, "Strategic Management of Human Capital in Public Education" (Madison, WI: Consortium for Policy Research in Education, 2008).

37 Strategic Management of Human Capital, "Taking Human Capital Seriously: Talented Teachers in Every Classroom, Talented Principals in Every School" (2009).

38 Daniel Weisberg and others, "The Widget Effect: Our National Failure to Acknowledge and Act on Differences in Teacher Effectiveness" (New York: The New Teacher Project, 2009).

39 Secretary Arne Duncan, The White House Blog, available at http://www.whitehouse.gov/blog/author/ Secretary\%20Arne\%20Duncan.

40 The four assurances were: adopting college and careerready academic standards and aligned assessments; developing longitudinal data systems from preschool through postsecondary education; increasing teacher effectiveness and ensuring an equitable distribution of effective teachers; and turning around the lowestperforming schools.

41 Allan Odden, Strategic Management of Human Capital In Education (New York: Routledge Press, 2011).

42 U.S. Department of Education, "Race to the Top Fund - States' Applications, Scores and Comments for Phase 1," available at http://www2.ed.gov/programs/racetothetop/phase1-applications/index.html.

43 Scott Laband, "Creating a Winning Legislative Campaign: The Colorado Story" (Washington: Democrats for Education Reform, 2011)

44 For example, see Craig Jerald, “Movin'It and Improvin' It: Using Both Strategies to Increase Teaching Effectiveness" (Washington: Center for American Progress, 2012).

45 Daniela Doyle and Jiye Grace Han, "Measuring Teacher Effectiveness: A Look 'Under the Hood' of Teacher Evaluation in 10 Sites" (New York; New Haven, CT; and Chapel Hill, NC: 50CAN, ConnCAN, and Public Impact, 2012); Sara Mead, "Recent State Action on Teacher Effectiveness: What's in State Laws and Regulations?" (Washington: Bellwether Education Partners, 2012); Glenda Partee, "Using Multiple Evaluation Measures to Improve Teacher Effectiveness: State Strategies from Round 2 of No Child Left Behind Act Waivers" (Washington: Center for American Progress, 2012).
46 U.S. Department of Education, "Teacher Incentive Fund," available at http://www2.ed.gov/programs/teacherincentive/index.html.

47 See "The Urban Schools Human Capital Academy," available at http://ushcacademy.org/.

48 Rhode Island Department of Elementary and Secondary Education, "Biography of the Commissioner," available at http://www.ride.ri.gov/Commissioner/ biography.aspx.

49 Tennessee Department of Education, "About the Commissioner," available at http://www.tn.gov/education/ AboutCommissioner.shtml.

50 Newark Trust for Education, "A brief bio of Newark's New Superintendent," May 4, 2011, available at http:// newarktrust.org/what-were-learning/69-bio-ofnewark-superintendent-cami-anderson.html; Stephen Sawchuk, "Approved Newark Teachers' Contract Creates Two-Tiered Salary Schedule," November 15, 2012, Teacher Beat blog, available at http://blogs.edweek. org/edweek/teacherbeat/2012/11/newark teachers_approve.html

51 Teach For America has increased the number of corps members from an initial 500 in its first year to almost six times that number now. Furthermore, Teach For America and TNTP recruits now comprise close to 50 percent of new math and science teachers in many urban districts. By focusing on high-poverty schools in urban and rural districts, Teach For America and TNTP have managed to operate "at scale" for these locations even though the number of new teachers they produce is a small percentage of the total needed all across the country.

52 Motoko Rich, "As the Chicago Strike Goes On, the Mayor Digs In," The New York Times, September 18, 2012, p. A1.

53 Measures of Effective Teaching Project, "Ensuring Fair and Reliable Measures of Effective Teaching" (Seattle: Bill \& Melinda Gates Foundation, 2013). Supporting reports available at http://www.metproject.org.

54 Odden, Strategic Management of Human Capital in Education

55 "Teachscape," available at http://www.teachscape.com/ (last accessed March 2013).

56 Stephen Sawchuk, "Teachers' Ratings Still High Despite New Measures," Education Week, February 6, 2013.

57 Henry and others, "Portal Report"; Noell and Gansl, "Teach for America Teachers' Contribution to Student Achievement in Louisiana in Grades 4-9"; Tennessee Higher Education Commission, "2010 Report Card on the Effectiveness of Teacher Training Programs"; Xu, Hannaway, and Taylor, "Making a Difference?"

58 One could also argue that movies such as "Waiting for Superman" and articles on how hard it is to dismiss ineffective teachers, such as the Steven Brill article in the Atlantic Monthly on the "rubber room" in New York City schools, helped create support for these initiatives among the professional elites in the country.

59 Political scientists argue that agenda-setting entails identifying a problem, having a solution to the problem, and getting political champions for the new policy issue, which seems to have happened with the talent issue in education. 



The Center for American Progress is a nonpartisan research and educational institute dedicated to promoting a strong, just, and free America that ensures opportunity for all. We believe that Americans are bound together by a common commitment to these values and we aspire to ensure that our national policies reflect these values. We work to find progressive and pragmatic solutions to significant domestic and international problems and develop policy proposals that foster a government that is "of the people, by the people, and for the people."

Center for American Progress 